\author{
ks. Tomasz Jelonek ${ }^{1}$ \\ Uniwersytet Papieski Jana Pawła II w Krakowie
}

\title{
Problem ubóstwa \\ w biblijnej koncepcji człowieka
}

Biblia jest przede wszystkim księgą religijną, która kieruje myśl czytelnika ku Bogu, Bóg natomiast przedstawiony w orędziu biblijnym jest Bogiem - Zbawicielem, który stale zwraca się ku człowiekowi, aby go zbawić, to znaczy obdarzyć szczęściem przez zjednoczenie ze sobą. Stąd w treści Biblii człowiek znajduje się na poczesnym miejscu, a Biblia ma swoistą i zwartą koncepcję człowieka, która zgodnie z prawami biblijnego objawienia stale się rozwijała, zachowując swoją ciągłość i podlegając transpozycji, to znaczy przeniesieniu na wyższy poziom, przy przejściu od Starego do Nowego Testamentu.

$1 \quad$ Ksiądz prałat Tomasz Bolesław Jelonek (ur. 1937) - przez kilka lat członek Zakonu Braci Mniejszych Kapucynów, obecnie konfrater, kapłan archidiecezji krakowskiej, magister i wykładowca matematyki na Uniwersytecie Jagiellońskim, teolog w dziedzinie teologii biblijnej z tytułem profesora, wykładowca na Papieskiej Akademii Teologicznej w Krakowie (dziś: Papieski Uniwersytet Jana Pawła II w Krakowie), podejmujący pracę naukową w zakresie programu Biblia w kulturze świata, promotor 20 doktorów, 30 licencjatów kościelnych oraz prawie 250 prac magisterskich z matematyki, teologii i nauk o rodzinie, autor licznych publikacji, obecnie profesor zwyczajny na Wydziale Nauk Społecznych UPJPII, członek zarządu Stowarzyszenia Biblistów Polskich I kadencji, wieloletni członek władz Polskiego Towarzystwa Teologicznego, a także przez wiele kadencji członek Zarządu Okręgu Krakowskiego Polskiego Towarzystwa Matematycznego, zaangażowany w odtwarzanie biblistyki słowackiej, wykładowca w seminariach duchownych na Ukrainie, kanonik honorowy Kapituły Metropolitalnej Lwowskiej. E-mail: tombojel@tlen.pl. 
Z wielu zagadnień, jakie wiążą się z biblijną koncepcją człowieka, chcemy podjać tu problem ubóstwa, które jest przedmiotem kolejnego sympozjum biblijnego organizowanego przez Zakon Braci Mniejszych Kapucynów, uczniów św. Franciszka Biedaczyny z Asyżu.

Człowiek do swego życia i działania potrzebuje różnych przedmiotów, narzędzi i środków, których używa lub którymi się posługuje. Jeżeli mu tego brakuje, mówimy o biedzie, a w wypadkach skrajnych o nędzy. Niedostatek rzeczy materialnych może być bardzo uciążliwy, ale na ogół zawsze istnieje możliwość, choć czasami bardzo nikła, że człowiek pozostający w biedzie będzie mógł z niej wyjść i uzyskać to, czego mu potrzeba, przynajmniej w skromnym zakresie. Gorzej jest, jeżeli brak dotyczy nie rzeczy zewnętrznych, ale kwalifikacji cielesnych lub duchowych, właściwych normalnemu człowiekowi. Jeśli są to braki cielesne, jak brak wzroku, słuchu, części ciała, w wielu wypadkach jesteśmy świadkami uciążliwej walki takiego człowieka z sobą samym, która często prowadzi do wspaniałych wyników w przezwyciężeniu słabości i kalectwa. Najgorszym brakiem jest brak kwalifikacji duchowych, a przede wszystkim niedorozwój umysłowy lub poważne obciążenia psychiczne. W tym wypadku nędza osiąga jakieś szczególne dno, od którego odbicie się jest bardzo trudne lub wręcz niemożliwe.

Wszystkie wspomniane tu przypadki braków, jakie są udziałem ludzi, określamy terminem „ubóstwo”, mówiąc bardziej szczegółowo o ubóstwie materialnym, fizycznym lub duchowym. Jednak termin „ubóstwo” ma także szersze zastosowanie i w sensie moralnym może oznaczać postawę wewnętrznej wolności względem posiadanych lub nieposiadanych dóbr materialnych, a w sensie religijnym oznacza wewnętrzne uzależnienie od Boga w odniesieniu do wszystkich potrzeb życiowych ${ }^{2}$.

Ubóstwo, zwłaszcza materialne, jest zjawiskiem stale towarzyszącym człowiekowi w jego dziejowej wędrówce przez ziemię. Jezus powiedział do uczniów zgorszonych czynem kobiety, która stłukła flakon olejku i wylała go na Jego głowę: „Ubogich zawsze macie z sobą, ale mnie nie zawsze mieć będziecie” (Mt 26, 11).

Por. Katolicyzm A-Z, pod red. Z. Pawlaka, Poznań 1982, s. 377. 
W myśli biblijnej obserwujemy bardzo charakterystyczną zmianę poglądów na przyczynę ubóstwa i jego znaczenie. W początkowych etapach dziejów zbawienia bogactwo człowieka uważano za przejaw szczególnego błogosławieństwa Bożego, a zatem ubóstwo było oznaką braku tego błogosławieństwa, co wiązało się z karą Bożą za grzechy. Zatem człowiek ubogi to człowiek grzeszny, zasługujący na gniew Boży.

Myśl ta została mocno wyakcentowana w niezwykłej medytacji na temat ludzkiego cierpienia i nędzy, jaką jest biblijna Księga Hioba ${ }^{3}$. Hiob był sprawiedliwy i dlatego Bóg obsypał go licznymi darami, miał dorodne dzieci i wielki majątek. Jednak Bóg poddał go próbie i zesłał nieszczęścia: w jednej chwili giną wszystkie dzieci, a majątek zostaje rozgrabiony. Na domiar złego ciało Hioba pokrywa trąd. W koncepcji ubóstwa i bogactwa, o jakiej wspominaliśmy powyżej, ten rozmiar nieszczęścia spadający na sprawiedliwego jest jakimś nieporozumieniem, wielką zagadką. Dlatego do Hioba przybywają trzej przyjaciele:

Usłyszeli trzej przyjaciele Hioba o wszystkim, co na niego spadło, i przyszli, każdy z nich z miejscowości swojej: Elifaz z Temanu. Bildad z Szuach i Sofar z Naamy. Porozumieli się, by przyjść, boleć nad nim i pocieszać go. Skoro jednak spojrzeli z daleka, nie mogli go poznać. Podnieśli swój głos i zapłakali. Każdy z nich rozdarł swe szaty i rzucał proch w górę na głowę. Siedzieli z nim na ziemi siedem dni i siedem nocy, nikt nie wyrzekł słowa, bo widzieli ogrom jego bólu (Hiob 2,11-13).

Pierwszy głos zabrał Hiob, a następnie przyjaciele prowadzili z nim długie rozmowy, w których chcieli go przekonać, że jego cierpienie musi być karą Boga za jakieś ukryte przewinienia, inaczej bowiem być nie może. Hiob bronił swej sprawiedliwości ${ }^{4}$ i kierował do Boga pytanie, dlaczego tej sprawiedliwości nie uwzględnia, postępując z nim w sposób, delikatnie mówiąc, niezrozumiały.

Księga Hioba jest medytacją religijną, która podejmuje trudny problem i próbuje ukazać nowe drogi myślenia. Dotychczasowy sposób traktowania ubóstwa i cierpienia jedynie jako kary Bożej musi być skorygowany, 
jeżeli bez naruszenia Bożej sprawiedliwości trzeba przyjąć, że ubóstwo i cierpienie może stać się udziałem także sprawiedliwego.

Pytanie o sens ubóstwa i cierpienia to pytanie, które stale powraca do ludzi z całą swoją ostrością. W konstrukcji Księgi Hioba po mowach jego przyjaciół, przeplatanych jego odpowiedziami, pojawia się tajemnicza postać Elihu, który także chce rozwikłać problem cierpienia, a ostatecznie przemawia sam Bóg. Kieruje on do Hioba pytania:

Gdzieś był, gdy zakładałem ziemię? Powiedz, jeżeli znasz mądrość. Kto wybadał jej przestworza? Wiesz, kto ją sznurem wymierzył? Na czym się słupy wspierają? Kto założył jej kamień węgielny ku uciesze porannych gwiazd, ku radości wszystkich synów Bożych? Kto bramą zamknął morze, gdy wyszło z łona wzburzone (Hiob 38, 4-8).

Tych pytań jest wiele i w końcu Hiob zrozumiał, że wobec tak wielkiej wiedzy i mądrości Boga musi ustąpić. „Jam mały, cóż Ci odpowiem? Rękę przyłożę do ust. Raz przemówiłem, nie więcej, drugi raz niczego nie dodam" (Hiob 40, 4-5). Jeżeli w stworzonym przez Boga świecie istnieje tyle tajemnic, których rozum ludzki nie może przeniknąć, to tym bardziej jakże może on rozwiązać tajemnicę cierpienia. Ubóstwo i cierpienie jest więc tajemnicą, ale dla Boga nie ma tajemnic ani w całym zewnętrznym świecie, ani w ludzkim życiu, On nad wszystkim panuje i wszystkim rządzi w mądrości5.

Ubóstwo i cierpienie, które jest dla człowieka niezrozumiałe, ma w Bożych planach swój sens, swoje znaczenie i chociaż człowiekowi wydaje się bezsensem, to prawdziwie nim nie jest. W przypadku Hioba było ono próbą, której nie wykorzystał, gdyż nie przyjął tej próby z całkowitym zaufaniem, że Bóg jest nie tylko sprawiedliwy, ale jest On Miłością, także wtedy, gdy dopuszcza na człowieka ubóstwo i cierpienie.

Zakończenie Księgi Hioba powraca do panującego wówczas sposobu myślenia i stwierdza, że sprawiedliwy Hiob po przejściu próby odzyskał dobra, które były poprzednio i są nadal bogactwem symbolizującym sprawiedliwość ich posiadacza.

5 Por. F. Chirpaz, Księga Hioba. Poemat o nadziei, przeł. A. Merdas, Poznań 1999, s. $107-129$. 
Chociaż to przedstawienie nie wychodzi poza zastany sposób patrzenia na ubóstwo i cierpienie, cała Księga jest ważnym etapem rozwoju myśli biblijnej na ten temat. Ubóstwo nie musi być wyrazem kary Bożej, a człowiek ubogi nie musi być grzesznikiem. Chociaż takie ubóstwo jest trudne do zrozumienia, to jednak ma ono swoje znaczenie w planach Bożych i może być dla człowieka przedmiotem zasługi, jeżeli podda się on tym planom, które są ostatecznie wyrazem Bożej mądrości i miłości.

Do tej medytacji religijnej z Księgi Hioba warto dodać inną medytację biblijną, jaką znajdujemy w Księdze Koheleta ${ }^{6}$. Nazwa „Kohelet” nie jest imieniem własnym, żaden z potomków Dawida takiego imienia nie nosił. W tytule i treści księgi znajdujemy nawiązanie do Salomona, on jednak nie jest autorem dzieła. Autor pozostaje zatem anonimowy, przypisuje sobie cechy Salomona dla podtrzymania konwencji literackiej, a kryje się pod nazwą Koheleta, która to nazwa odnosi się do funkcji w zgromadzeniu liturgicznym. Zwołanie wspólnoty, zgromadzenie religijne określano nazwą hebrajską qahal. Określenie przypisane autorowi księgi pochodzi od tego terminu. Jest to nazwa funkcji sprawowanej w izraelskim zgromadzeniu religijnym. Nie wiemy jednak, o jaką konkretnie funkcję chodzi, opinie specjalistów są bowiem podzielone. Najbardziej prawdopodobną jest opinia, która w kohelecie widzi przemawiającego na zgromadzeniu, kaznodzieję.

Pod nazwą określającą funkcję ukrył się mędrzec nieprzeciętny. Poruszył on wszystkie najbardziej istotne zagadnienia związane z wewnętrznymi przeżyciami człowieka, jego pytaniami i wątpliwościami, których objawienie Starego Testamentu jeszcze nie rozwiązało, zapuścił się jeszcze głębiej w labirynt odkryty przez Hioba i, chociaż daremnie poszukuje wyjścia, kurczowo trzyma się także wiary w Boga.

Księga Koheleta jest swoistą filozofią życia, podejmującą temat jego wartości. Główne rozwiązanie Księgi można streścić w kilku punktach. Autor stwierdza, że wszystko co ziemskie (należące do sfery pod słońcem) jest marnością. Bóg natomiast sprawuje nad wszystkim swe rządy. Człowiek powinien korzystać z uciech, jakie istnieją, ale w sposób umiar-

6 Por. G. Ravasi, Kohelet. Najbardziej oryginalnai ,skandaliczna” księga Starego Testamentu, tłum. J. Skrzypnik, Kraków 2003, passim. 
kowany. Powinien również pracować, gdyż przed Bogiem będzie odpowiadał za swoje czyny. Autor wyznaje swoją wiarę w nieśmiertelność duszy. Wszystko jest przemijające i niegodne nakładu sił, ale prawda ta nie może usprawiedliwiać zaniechania działalności

O ile Hiob stanął wobec problemu cierpienia człowieka sprawiedliwego, o tyle Kohelet podejmuje problem od drugiej strony, dla niego zagadnieniem jest, dlaczego niesprawiedliwy nie cierpi i jego los nie różni się od losu sprawiedliwego. To rozważanie także podaje w wątpliwość przekonanie o tym, że cierpienie, a także ubóstwo jest skutkiem złego postępowania tego, kto cierpi.

Ten znak zapytania jeszcze dobitniej postawiło samo życie społeczne, którego obserwacja prowadziła do wniosku, że ubóstwo jest bardziej skutkiem niesprawiedliwości społecznej niż sprawiedliwości Bożej. Bogaci, a więc ci, którzy mieliby być wynagrodzonymi przez Boga za swoją sprawiedliwość, najczęściej okazywali się gnębicielami ubogich i sprawcami jeszcze głębszego ich ubóstwa.

Dlatego w pismach prorockich znajdujemy bardzo liczne napomnienia, kierowane przeciw bogatym i możnym, których bogactwo w wielu wypadkach rosło na ludzkiej krzywdzie ${ }^{8}$ :

Słuchajcie słowa tego, krowy Baszanu, które mieszkacie na górach Samarii: uciskacie biednych, gnębicie ubogich, mówicie do mężów swoich: Przynieś, a będziemy pili! (Am 4,1).

Krowami Baszanu, które karmiły się na szczególnie obfitych pastwiskach tamtej krainy i odznaczały się dobrym wyglądem, prorok nazywa ludzi obfitujących w bogactwo, należących do wyższych sfer Królestwa Północnego (Samarii) ${ }^{9}$. Przykładami tego rodzaju wypowiedzi mogą być także:

Am 2, 6-7:Tak mówi Pan: Z powodu trzech występków Izraela i z powodu czterech nie odwrócę tego [wyroku], gdyż sprzedają za srebro sprawiedliwego, a ubogiego Wszystkich).

Por. T. Jelonek, Kohelet i Syrach. Dwaj mędrcy Izraela, Kraków 1992, s. 12 (Biblia dla

Por. G. Witaszek, Myśl spoteczna proroków, Lublin 1998.

O wypowiedziach Amosa na temat ucisku por. G. Witaszek, Prorocy Amos i Micheasz wobec niesprawiedliwości społecznej, Tuchów 1992. 
za parę sandałów; w prochu ziemi depcą głowy biednych i ubogich kierują na bezdroża; ojciec i syn chodzą do tej samej dziewczyny, aby znieważać święte imię moje.

Am 5, 11-12: Ponieważ deptaliście biednego i daniny w zbożu braliście od niego, możecie zbudować sobie domy z kamienia ciosanego, lecz nie będziecie w nich mieszkali; możecie piękne winnice zasadzić, lecz nie będziecie pili z nich wina. Albowiem poznałem mnogie wasze złości i grzechy wasze liczne, o wy, ciemięzcy sprawiedliwego, biorący okup i uciskający w bramie ubogich!

Iz 3, 14-15: Pan wchodzi na rozprawę ze starszymi swego ludu i z jego książętami: To wyście spustoszyli winnicę, coście biednemu zrabowali, jest w waszych domach. Jakim prawem uciskacie mój lud i przygnębiacie oblicza ubogich? Wyrocznia Pana, Boga Zastępów.

Iz 10,1-2: Biada prawodawcom ustaw bezbożnych i tym, co ustanowili przepisy krzywdzące, aby słabych odepchnąć od sprawiedliwości i wyzuć z prawa biednych mego ludu; by wdowy uczynić swoim łupem i by móc ograbiać sieroty!

W świetle tych wypowiedzi dochodzimy do przekonania, że bogactwo i władza dają możność krzywdzenia innych, a przede wszystkim ludzi ubogich, których ubóstwo staje się sytuacją wołającą do nieba o sprawiedliwość. Bóg jest obrońcą uciśnionych:

Ps 72, 4-5. 12-14: otoczy opieką uciśnionych z ludu, ratować będzie dzieci ubogich, a zetrze ciemiężyciela. I będzie trwał długo jak słońce, jak księżyc przez wszystkie pokolenia... Wyzwoli bowiem wołającego biedaka i ubogiego, i bezbronnego. Zmiłuje się nad nędzarzem i biedakiem i ocali życie ubogich: uwolni ich życie od krzywdy i ucisku, a krew ich cenna będzie w jego oczach.

Porównaj także:

Ps 10, 1-2: Dlaczego z dala stoisz, o Panie, w czasach ucisku się kryjesz, gdy występny się pyszni, biedny jest w udręce i ulega podstępom, które tamten uknuł?

Ps 10, 12-14: Powstań, o Panie, wznieś swą rękę, Boże! Nie zapominaj o biednych! Dlaczego występny gardzi Bogiem, mówi w swym sercu: Nie pomści? A Ty widzisz trud i boleść, patrzysz, by je wziąć w swoje ręce. Tobie się biedny poleca, Tyś opiekunem sieroty!

Ps 140, 13-14: Wiem, że Pan oddaje sprawiedliwość ubogiemu, biednemu - słuszność. Tylko sprawiedliwi będą sławili Twe imię, prawi mieszkać będą przed Twoim obliczem. 
Bóg nie tylko broni ubogiego wtedy, gdy uciska go niesprawiedliwy, gdy możny go prześladuje, Bóg również zadbał o ubogich, ustanawiając swoje Prawo i swoją troską obejmuje wszystkich, nawet cudzoziemców.

\begin{abstract}
Jeśli bliźniemu swemu udzielisz pożyczki z zabezpieczeniem, nie wejdziesz do jego domu, by zabrać cośkolwiek w zastaw. Na dworze będziesz stał, a człowiek, któremu pożyczyłeś, wyniesie ci ten zastaw na zewnątrz. Wszakże jeśli to jest człowiek ubogi, nie położysz się spać nakryty tym zastawem, lecz zwrócisz mu zastaw przed zachodem słońca, aby mógł spać pod swym płaszczem, błogosławiąc tobie, a Pan, Bóg twój, policzy ci to za dobry czyn. Nie będziesz niesprawiedliwie gnębił najemnika ubogiego i nędznego, czy to będzie brat twój, czy obcy, o ile jest w twoim kraju, w twoich murach. Tegoż dnia oddasz mu zapłatę, nie pozwolisz zajść nad nią słońcu, gdyż jest on biedny i całym sercem jej pragnie; by nie wzywał Pana przeciw tobie, a to by cię obciążyło grzechem.
\end{abstract}

Nie będziesz łamał prawa obcokrajowca i sieroty ani nie weźmiesz w zastaw odzieży od wdowy. Pamiętaj, żeś był niewolnikiem w Egipcie i wybawił cię stamtąd Pan, Bóg twój; dlatego to ja ci nakazuję zachować to prawo. Jeśli będziesz żął we żniwa na swoim polu i zapomnisz snopka na polu, nie wrócisz się, aby go zabrać, lecz zostanie dla obcego, sieroty i wdowy, aby ci błogosławił Pan, Bóg twój, we wszystkim, co czynić będą twe ręce. Jeśli będziesz zbierał oliwki, nie będziesz drugi raz trząsł gałęzi; niech zostanie coś dla obcego, sieroty i wdowy. Gdy będziesz zbierał winogrona, nie szukaj powtórnie pozostałych winogron; niech zostaną dla obcego, sieroty i wdowy. Pamiętaj, żeś i ty był niewolnikiem w ziemi egipskiej; dlatego ja ci nakazuję zachować to prawo (Pwt 24, 10-15. 17-22).

Człowiek ubogi został otoczony opieką Boga, który tę opiekę, zapisawszy w Prawie, zleca ludzkiej społeczności. Wobec różnych okrucieństw, jakie obserwujemy w historii świata, Prawo ustanowione przez Boga jest rzeczywiście prawem najbardziej humanitarnym. W świecie bowiem rządzą ludzie możni i bogaci, często bezwzględni w dążeniu do swoich egoistycznych celów. Prawo Boże natomiast spogląda na człowieka będącego w potrzebie, dostrzega jego potrzeby i nakazuje wyjść im naprzeciw. Z tym wiąże się także podkreślenie roli jałmużny, która jest jednym z istotnych elementów biblijnej pobożności. Przez jałmużnę wspiera się tych, którzy są w potrzebie, a równocześnie dla siebie zdobywa bogactwo duchowe.

W Starym Testamencie znajdujemy wspaniały przykład człowieka, który sam daje jałmużnę i o jej potrzebie oraz wartości poucza swego syna. Jest to Tobiasz, który nawet na wygnaniu obdarowuje ubogich i którego życie tak zostało scharakteryzowane: 
Umarł on w pokoju mając sto dwanaście lat i pogrzebano go uroczyście w Niniwie. A miał sześćdziesiąt dwa lata, kiedy zasłabł na oczy. A po przejrzeniu żył w dobrobycie i dawał jałmużny. W dalszym ciągu uwielbiał Boga i oddawał hołd majestatowi Bożemu $(\mathrm{Tb} 14,2)$.

Tobiasz także wielokrotnie poucza swego syna na temat jałmużny. Przytoczymy to pouczenie, które jest zobrazowaniem biblijnego pouczenia o postępowaniu wobec ludzi ubogich.

Tb 4, 8-11: Jak ci tylko starczy, według twojej zasobności dawaj z niej jałmużnę! Będziesz miał mało - daj mniej, ale nie wzbraniaj się dawać jałmużny nawet z niewielkiej własności! Tak zaskarbisz sobie wielkie dobra na dzień potrzebny, ponieważ jałmużna wybawia od śmierci i nie pozwala wejść do ciemności. Jałmużna bowiem jest wspaniałym darem dla tych, którzy ją dają przed obliczem Najwyższego.

Tb 4, 16: Udzielaj twego chleba głodnemu, a szat swoich użycz nagim! Ze wszystkiego, co ci zbywa, dawaj jałmużnę, a oko twoje niech nie będzie skąpe, gdy ją dajesz.

Tb 12, 8-9: Lepsza jest modlitwa ze szczerością i miłosierdzie ze sprawiedliwością aniżeli bogactwo z nieprawością. Lepiej jest dawać jałmużnę, aniżeli gromadzić złoto. Jałmużna uwalnia od śmierci i oczyszcza z każdego grzechu. Ci, którzy dają jałmużnę, nasyceni będą życiem.

Tb 14, 8: A teraz, dzieci, rozkazuję wam: Służcie Bogu w prawdzie i czyńcie, co podoba się Jemu. Dzieciom waszym polećcie wykonywać sprawiedliwość i dawać jałmużnę i niech pamiętają o Bogu, i wielbią Imię Jego w każdej chwili, w prawdzie i z całej siły.

Tb 14, 11: Tak teraz, dzieci, patrzcie, jakie skutki sprawia dawanie jałmużny, a jakie popełnianie nieprawości, że mianowicie ona zabija. A oto i dusza moja opuszcza mnie. I położono go na łóżku, i umarł. Pochowano go uroczyście.

\section{To pouczenie można uzupełnić aforyzmami z Księgi Syracha:}

Woda gasi płonący ogień, a jałmużna gładzi grzechy (Syr 4, 30).

Niech ci nie zabraknie ufności w czasie twej modlitwy i nie zaniedbuj czynić jałmużny! (Syr 8, 10).

Jałmużna męża jest u Niego jak pieczęć, a dobrodziejstwa człowieka chowa jak źrenicę oka (Syr 18, 21). 
Poza tym bądź dla biednego łaskawy i nie daj mu długo czekać na jałmużnę! Zgodnie z przykazaniem przyjdźz pomocą biednemu i stosownie do jego potrzeby nie odsyłaj go z pustymi rękami! Strać raczej pieniądze dla brata i przyjaciela, niżby miały zardzewieć, zmarnować się pod kamieniem. Umieść skarb twój według przykazań Najwyższego, a korzystniejsze to będzie dla ciebie niż złoto. Zamknij jałmużnę w spichlerzach twoich, a ona wybawi cię z każdego nieszczęścia. Lepiej niż tarcza mocna, niżeli ciężka włócznia za ciebie walczyć będzie z wrogiem (Syr 30, 8-13).

Kto świadczy dobrodziejstwa, przynosi ofiary z najczystszej mąki, a kto daje jałmużnę, składa ofiarę uwielbienia (Syr 36, 2).

Dobroczynność jest jak raj we wszystko obfitujący, a jałmużna - trwa na wieki (Syr 41,17).

Do tego starotestamentowego pouczenia na temat jałmużny dodajmy jeszcze wskazanie Jezusa:

Kiedy więc dajesz jałmużnę, nie trąb przed sobą, jak obłudnicy czynią w synagogach i na ulicach, aby ich ludzie chwalili. Zaprawdę, powiadam wam: ci otrzymali już swoją nagrodę. Kiedy zaś ty dajeszjałmużnę, niech nie wie lewa twoja ręka, co czyni prawa, aby twoja jałmużna pozostała w ukryciu. A Ojciec twój, który widzi w ukryciu, odda tobie (Mt 6, 2-4).

Ubóstwo materialne jest zatem zjawiskiem bardzo powszechnym, a jałmużna przychodzi potrzebującemu z pomocą. Bóg dopuszcza biedę materialną, aby dla doznających ją była próbą, a dla innych okazją do dawania jałmużny, której wielką wartość śledziliśmy na podstawie tekstów biblijnych, zaczerpniętych przede wszystkim z Księgi Tobiasza oraz z Księgi Syracha.

Pismo Święte nie tylko zajmuje się sprawą materialnego ubóstwa, na jego kartach ukazana jest wspaniała postawa człowieka, który wobec wszystkich dóbr tego świata zachowuje swoją wolność, bogactwo nie zaślepia jego umysłu i nie wiąże serca, które wolne od przywiązania do rzeczy materialnych, może otworzyć się całkowicie na Boga ${ }^{10}$. Taką postawę praktykowali już sprawiedliwi Starego Testamentu, których nazywa-

10 Por. L. Roy, Ubóstwo, [w:] Słownik teologii biblijnej, pod red. X. Léon-Dufoura, tłum. i oprac. K. Romaniuk, Poznań 1973, s. 998. 
my anawim Jahwe - ubogimi Jahwe. Do nich zalicza się Maryja, służebnica Pańska, która wyśpiewała swój hymn całkowitej zależności od Pana, zapisany w Ewangelii Łukaszowej. Jezus urodził się w warunkach skrajnego ubóstwa, na Jego spotkanie wychodzą ubodzy Jahwe: Symeon i Anna, również uczniów będzie uczył tej postawy.

Na końcu drogi rozwojowej biblijnego pouczenia ubóstwo staje się znakiem Bożego upodobania, a bogactwo nie musi być wyrazem Bożego błogosławieństwa. Jest ono często niebezpieczeństwem zagrażającym prawdziwemu dobru człowieka.

Jezus zaś powiedział do swoich uczniów: Zaprawdę, powiadam wam: Bogaty z trudnością wejdzie do królestwa niebieskiego. Jeszcze raz wam powiadam: Łatwiej jest wielbłądowi przejść przez ucho igielne niż bogatemu wejść do królestwa niebieskiego (Mt 19, 23-24).

Królestwo Boże obiecane jest bowiem ubogim w duchu, „błogosławieni ubodzy w duchu, albowiem do nich należy królestwo niebieskie" (Mt 5, 3). W tym duchu trzeba rozumieć stwierdzenie, że w Ewangelii według św. Łukasza ukazane jest bogactwo ubogich i ubóstwo bogatych. Ubodzy w dobra materialne mają bogactwo dóbr duchowych, a bogaci pod względem materialnym bardzo często duchowo są ubodzy i wobec Boga są jak ci mieszkańcy Laodycei, do których w Apokalipsie Jezus poprzez Jana kieruje słowa:

Ty bowiem mówisz: Jestem bogaty, i wzbogaciłem się, i niczego mi nie potrzeba, a nie wiesz, że to ty jesteś nieszczęsny i godzien litości, i biedny i ślepy, i nagi. Radzę ci kupić u mnie złota w ogniu oczyszczonego, abyś się wzbogacił, i białe szaty, abyś się oblókł, a nie ujawniła się haniebna twa nagość, i balsamu do namaszczenia twych oczu, byś widział (Ap 3,17-18).

Materialne bogactwo, a także materialne ubóstwo nie stanowią istotnej sprawy w życiu człowieka. Jego prawdziwą wartością, która liczy się wobec Boga i decyduje o osiągnięciu ostatecznego celu, jest ubóstwo duchowe, które ustanawia poprawną hierarchię wszystkich wartości. Naczelną jest Bóg, któremu należy całkowicie zaufać, a to zaufanie zawsze będzie busolą, która może tak poprowadzić człowieka wobec bogactwa lub ubóstwa, aby jedno i drugie mogło mu służyć w odpowiadaniu na skierowa- 
ny ku niemu Boży plan zbawienia. Tę postawę pięknie wyraża św. Paweł w Liście do Filipian:

Ja bowiem nauczyłem się wystarczać sobie w warunkach, w jakich jestem. Umiem cierpieć biedę, umiem i obfitować. Do wszystkich bowiem warunków jestem zaprawiony: i być sytym, i głód cierpieć, obfitować i doznawać niedostatku. Wszystko mogę w Tym, który mnie umacnia (Flp 4, 11-13). 


\section{Summary}

\section{Problem ubóstwa w biblijnej koncepcji człowieka}

Wszystkie przypadki braków, jakie są udziałem ludzi, określamy terminem „ubóstwa”, mówiąc bardziej szczegółowo o ubóstwie materialnym, fizycznym lub duchowym. Jednak termin „ubóstwo” ma także szersze zastosowanie i w sensie moralnym może oznaczać postawę wewnętrznej wolności względem posiadanych lub nieposiadanych dóbr materialnych, a w sensie religijnym oznacza wewnętrzne uzależnienie od Boga w odniesieniu do wszystkich potrzeb życiowych. W myśli biblijnej obserwujemy bardzo charakterystyczną zmianę poglądów na przyczynę ubóstwa i jego znaczenie. W początkowych etapach dziejów zbawienia bogactwo człowieka uważano za przejaw szczególnego błogosławieństwa Bożego, a zatem ubóstwo było oznaką braku tego błogosławieństwa, co wiązało się z karą Bożą za grzechy. Zatem człowiek ubogi to człowiek grzeszny, zasługujący na gniew Boży. Myśl ta bardzo dobitnie została wyakcentowana w niezwykłej medytacji na temat ludzkiego cierpienia i nędzy, jaką jest biblijna Księga Hioba. Księga ta jest ważnym etapem rozwoju myśli biblijnej na ten temat. Ubóstwo nie musi być wyrazem kary Bożej, a człowiek ubogi nie musi być grzesznikiem. Materialne bogactwo, a także materialne ubóstwo nie stanowią istotnej sprawy w życiu człowieka. Jego prawdziwą wartością, która liczy się wobec Boga i decyduje o osiągnięciu ostatecznego celu, jest ubóstwo duchowe, które ustanawia poprawną hierarchię wszystkich wartości. Naczelną jest Bóg, któremu należy całkowicie zaufać, a to zaufanie zawsze będzie busolą, która może tak poprowadzić człowieka wobec bogactwa lub ubóstwa, aby jedno i drugie mogło mu służyć w odpowiadaniu na skierowany ku niemu Boży plan zbawienia.

Słowa kluczowe: ubóstwo, bogactwo, Księga Hioba; Księga Koheleta, Księga Tobiasz, hierarchia wartości

\section{The Problem of Poverty in Biblical Concept of Man}

All the cases of deprivation which people suffer from are called poverty. To be more specific, there is material poverty, physical poverty and spiritual poverty. However, the term poverty has also a broader use, and in a moral sense can mean the attitude of internal freedom towards material possessions. In a religious sense it is internal dependence on God when it comes to all necessities of life. In Biblical thought one can observe a very characteristic change of views on the reason of poverty and its meaning. At the beginning stages of history of salvation wealth of a man was considered as a sign of God's special blessing, whereas poverty was the indication of lack of such a blessing, which was connected with God's punishment for sins. A poor man therefore, is a sinful man deserving God's wrath. This thought was very clearly 


\section{ks. Tomasz Jelonek}

accentuated in the biblical Book of Job, which is an extraordinary meditation on human suffering and poverty. This book is a very important stage in the development of the biblical thought concerning this matter. Poverty does not necessarily have to be an indication of God's punishment and a poor man does not have to be a sinner. Material wealth as well as material poverty do not have significant meaning in man's life. Its true value is spiritual poverty, which counts for God and which determines the right hierarchy of all the values. The ultimate value in this hierarchy is God who is to be totally trusted in. This trust is a kind of lodestar which can lead man through life in such a way that both wealth and poverty will serve him to follow God's salvation plan.

Keywords: poverty, wealth, the Book of Job, the Book of Ecclesiastes, the Book of Tobit, hierarchy of values

\section{Bibliografia}

Bremer J., Hiob: obrońca własnej prawości, Kraków 2002.

Chirpaz F., Księga Hioba. Poemat o nadziei, przeł. A. Merdas, Poznań 1999.

Jelonek T., Kohelet i Syrach. Dwaj mędrcy Izraela, Kraków 1992 (Biblia dla Wszystkich). Katolicyzm A-Z, pod red. Z. Pawlaka, Poznań 1982.

Ravasi G., Hiob. Dramat Boga i człowieka, t. 1, przeł. B. Rzepka, Kraków 2004,

Ravasi G., Hiob. Dramat Boga i człowieka, t. 2 przeł. K. Stopa, Kraków 2005.

Ravasi G., Kohelet. Najbardziej oryginalna $i$,skandaliczna" księga Starego Testamentu, tłum. J. Skrzypnik, Kraków 2003.

Słownik teologii biblijnej, pod red. X. Léon-Dufoura, tłum. u oprac. K. Romaniuk, Poznań 1973.

Witaszek G., Myśl społeczna proroków, Lublin 1998.

Witaszek G., Prorocy Amos i Micheasz wobec niesprawiedliwości społecznej, Tuchów 1992. 